\title{
Pengaruh Penambahan Buah Nangka Muda terhadap Sifat Fisik dan Organoleptik Abon Daging Itik Afkir
}

\author{
Rasman $^{1}$, Harapin Hafid ${ }^{2}$, Nuraini ${ }^{2}$ \\ ${ }^{1}$ Mahasiswa Fakultas Peternakan Universitas Halu Oleo \\ ${ }^{2}$ Fakultas Peternakan Universitas Halu Oleo \\ Jl. H.E.A. Mokodompit Kampus Hijau Bumi Tridharma, Anduonohu, Kendari 93232 \\ *Email korespondensi: harapin.hafid@uho.ac.id
}

(Diterima: 16-7-2018; disetujui 21-9-2018)

\begin{abstract}
ABSTRAK
Penelitian ini dilakukan untuk mengetahui sifat fisik dan organoleptik abon daging itik afkirdengan penambahan buah nangka muda. Bahan yang digunakan adalah daging itik afkir, buah nangka muda, bawang putih, bawang merah, kemiri, ketumbar, kelapa, gula merah, garam, air, dan minyak goreng. Rancanganpenelitian yang digunakan dalam penelitian ini yaitu rancangan acak lengkap terdiri dari 4 perlakuan (A0: 100\% daging itik, A1: 85\% daging itik dan 15\% nangka muda, A2:70\% daging itik dan 30\% nangka muda,A3:55\% daging itik dan 45\% nangka muda) dengan3 ulangan untuk peubah fisik, dan 15 panelis untuk pengujian organoleptik.Hasil penelitian menunjukan bahwa penambahan buah nagka muda padaabon itik afkir tidak berpengaruh nyata terhadap $\mathrm{pH}$ dan rendemen abon. Sifat organoleptik (aroma, warna, rasa, dan tekstur)abon daging itik afkir tidak berbeda nyata dengan penambahan buah nangka muda.
\end{abstract}

Katakunci: Abon, daging itik afkir, buah nangka muda, sifat fisik, sifat organoleptik.

\begin{abstract}
This study was conducted to determine the physical characteristics and organoleptic qualities of spent duck abon with the addition of unripe jackfruit. The materials used were spent duck meat, unripe jackfruit, garlic, shallot, candlenut, coriander, coconut, brown sugar, salt, water, and cooking oil. The design used in this study is completely randomized design consisted of 4 treatment (A0: 100\% duck meat, A1: $85 \%$ duck meat and 15\% unripe jackfruit, A2: 70\% duck meat and 30\% unripe jackfruit, A3: 55\% duck meat and $45 \%$ unripe jackfruit) with 3 repetition for physical variables, and 15 panelists for organoleptic test. The results of this study suggested that addition of unripe jackfruit in spent duck abon showed no significant difference for $\mathrm{pH}$ and rendemen. Organoleptic qualities (aroma, color, flavor and texture) of spent duck abon showed no significant difference with unripe jackfruit aditition.
\end{abstract}

Keywords: abon, spent duck meat, unripe jackfruit, physical characteristic, organoleptic qualities

\section{PENDAHULUAN}

Majunya perkembangan teknologi pangan dewasa ini telah mendorong inovasi dan kreatifitas untuk memperoleh bahan baku pengolahan pangan yang murah. Selain murah produk bahan baku tersebut harus memenuhi syarat bernilai gizi tinggi, mudah didapatkan dan dapat diterima masyarakat (Hafid, 2017; Hafid et al., 2017). Daging itik sebagai salah satu sumber protein hewani asal unggas belum cukup populer dikalangan konsumen karena sunber peotein hewani masih bertumpu pada ayam pedaging, ayam petelur, dan ayam kampung. Padahal daging itik dapat dijadikan sebagai sumber alternatif untuk memenuhi gizi masyarakat. Menurut Randa et al. (2002) dan Joseph et al. (2002) daging itik kurang digemari masyarakat karena baunya yang anyir dan alot. 
Cara untuk meningkatkan konsumsi daging itik maka perlu dilakukan pengolahan lanjutan menjadi suatu produk pangan berupa abon yang dapat menambah cita rasa dan memperpanjang daya simpan sehingga tidak mudah rusak (Hafid, 2017). Abon termasuk makanan ringan atau lauk yang siap saji. Produk tersebut sudah dikenal oleh masyarakat umum sejak dulu. Abon dibuat dari daging yang diolah sedemikian rupa sehingga memiliki karakteristik kering, ringan, renyah, dan gurih.

Pembuatan abon dari daging itik ini dapat ditambahkan atau disubtitusi dengan bahan lain seperti buah nangka muda. Penambahan ini bertujuan untuk menekan biaya penggunaan daging itik seratus persen, dimana buah nangka muda atau lazim dinamakan gori juga termasuk salah satu bahan makanan yang berpotensi untuk diversifikasi sebagai pangan karena komponen gizinya yang cukup berarti yaitu karbohidrat serta memiliki serat yang mirip dengan serat daging.

\section{MATERI DAN METODE}

\section{Materi}

Materi yang digunakan dalam penelitian ini adalah abon dengan bahan utama daging itik dan buah nangka muda yang diperoleh dari pedagang di pasar PKL (Pedagang Kaki Lima) Kota Kendari, dan bumbu-bumbu (yang terdiri dari bawang putih, bawang merah, kemiri, ketumbar, kelapa, gula merah dan garam) air, dan minyak goreng.

Alat yang digunakan yaitu pisau, panci, talenan, timbangan analitik, wajan, dandang, blender, kompor, waterbath baskom, saringan kelapa, $\mathrm{pH}$ meter dan blanko uji hedonik.

\section{Metode}

Penelitian ini dilakukan secara eksprimental menggunakan rancangan acak lengkap dengan perlakuan I jenis pembuatan abon daging itik afkir tanpa penambahan buah nangka muda sebagai kontrol, perlakuan II, penambahan buah nangka muda sebanyak $15 \%$, perlakuan III penambahan buah nangka muda sebanyak $30 \%$, dan perlakuan IV penambahan buah nangka muda sebanyak $45 \%$ dari jumlah daging itik afkir yang digunakan. Setiap jenis perlakuan dilakukan dengan tiga kali ulangan. Selanjutnya analisis data dilakukan dengan analisis ragam.

\section{Variabel Penelitian}

\section{Pengujian Kualitas Fisik Abon}

\section{pH abon}

Uji pH menurut Soeparno (2005), yaitu sampel daging abon 10 gram dihaluskan, kemudian dicampurkan dengan $10 \mathrm{ml}$ aquadest kemudian diaduk hingga homogen. $\mathrm{pH}$ meter dibersihkan dengan aquadest dan dimasukan ke buffer $\mathrm{pH} 7$ untuk disesuaikan pH-nya. Setiap larutan diukur $\mathrm{pH}-$ nya sebanyak tiga kali dan hasilnya di rata- ratakan sebagai nilai $\mathrm{pH}$ abon.

\section{Rendemen abon}

Rendemen merupakan perbandingan berat produk dengan berat bahan x 100\%, (Hafid, 2004), nilai randemen abon dapat dihitung dengan rumus sebagai berikut:

$$
\text { Rendemen }(\%)=\frac{\text { Berat abon }}{\text { Bahan Baku }} \times 100 \%
$$

\section{Pengujian Kualitas Organoleptik}

Data yang dikumpulkan meliputi data organoleptik berupa tingkat kesukaan panelis (skala hedonik) terhadap warna, aroma, tekstur, dan rasa abon yang dilakukan dengan uji organoleptik. Pengujian organoleptik dilakukan dengan uji kesukaan dimana panelis diminta memberikan tingkatan kesukaan atau ketidaksukaan terhadap sampel yang diuji pada formulir uji organoleptik. Skala hedonik dapat dilihat pada Tabel 2 .

Tabel 1. Komposisi abon daging itik dengan penambahan buah nangka muda

\begin{tabular}{lllll}
\hline Komposisi abon & A0 & A1 & A2 & A3 \\
\hline Daging (g) & 1000 & 850 & 700 & 550 \\
Nangka muda (g) & 0 & 150 & 300 & 450 \\
Ketumbar (g) & 5 & 5 & 5 & 5 \\
Kemiri (g) & 25 & 25 & 25 & 25 \\
Gula Merah (g) & 70 & 70 & 70 & 70 \\
Bawang Putih (g) & 10 & 10 & 10 & 10 \\
Bawang Merah (g) & 30 & 30 & 30 & 30 \\
Garam (g) & 20 & 20 & 20 & 20 \\
Kelapa (g) & 600 & 600 & 600 & 600 \\
\hline
\end{tabular}

Sumber: Tetty et al., (2007) dimodifikasi 
Tabel 2.Parameter yang diukur pada uji organoleptik

\begin{tabular}{|c|c|c|}
\hline Peubah & Skala Hendonik & Kriteria \\
\hline \multirow[t]{5}{*}{ Warna } & 1 & Sangat disukai \\
\hline & 2 & Disukai \\
\hline & 3 & Cukup disukai \\
\hline & 4 & Tidak disukai \\
\hline & 5 & Sangat tidak disukai \\
\hline \multirow[t]{5}{*}{ Aroma } & 1 & Sangat disukai \\
\hline & 2 & Disukai \\
\hline & 3 & Cukup disukai \\
\hline & 4 & Tidak disukai \\
\hline & 5 & Sangat tidak disukai \\
\hline \multirow[t]{5}{*}{ Rasa } & 1 & Sangat disukai \\
\hline & 2 & Disukai \\
\hline & 3 & Cukup disukai \\
\hline & 4 & Tidak disukai \\
\hline & 5 & Sangat tidak disukai \\
\hline \multirow[t]{5}{*}{ Tekstur } & 1 & Sangat disukai \\
\hline & 2 & Disukai \\
\hline & 3 & Cukup disukai \\
\hline & 4 & Tidak disukai \\
\hline & 5 & Sangat tidak disukai \\
\hline
\end{tabular}

Sumber : Hafid \& Syam (2007); Hafid et al., (2014); Hafid et al., (2017)

\section{HASIL PENELITIAN}

\section{pH Abon}

Nilai $\mathrm{pH}$ merupakan salah satu faktor yang mempengaruhi kualitas abon. Nilai $\mathrm{pH}$ abon daging itik dengan penambahan buah nangka mudah yaitu dapat dilihat pada Tabel 3 . Berdasarkan analisis ragam terhadap $\mathrm{pH}$ abon daging itik dan dengan penambahan buah nangka tidak memberikan pengaruh nyata $(\mathrm{P}>0,05)$. Kisaran $\mathrm{pH}$ yang diperoleh dalam penelitian ini yaitu antara 4,33-4,97\%, ini menunjukan bahwa nilai $\mathrm{pH}$ abon pada penelitian ini cenderung asam. Hal ini dapat terjadi karena adanya penambahan bumbu-bumbu seperti gula pada pembuatan abon daging itik. Menurut Pursudarsono et al. (2015) semakin banyak penambahan gula maka nilai $\mathrm{pH}$ akan cenderung meningkat. Daya mengikat air dipengaruhi oleh faktor $\mathrm{pH}$, pelayuan, pemanasan, spesies, umur, fungsi otot, penyimpanan dan preservasi, jenis kelamin, kesehatan, perlakuan sebelum pemotongan dan lemak intramuscular (Soeparno, 2005; Hafid, 2017).

\section{Rendemen abon}

Rendemen abon merupakan presentase abon yang diperoleh berdasarkan total berat bahan baku yang digunakan, yaitu berat daging itik afkir dan buah nangka muda. Nilai rata-rata rendemen abon menurut jenis perlakuan dapat dilihat pada Tabel 4. Berdasarkan hasil analisis ragam terhadap rendemen abon daging itik dengan penambahan buah nangka muda tidak berpengaruh nyata pada setiap perlakuan $(\mathrm{P}<0,05)$. Rendemen abon yang dihasilkan menurut semua jenis perlakuan berkisar antara 28$35 \%$. Hasil penjabaran tersebut diperoleh rataan tertinggi yaitu perlakuan A2(700 g daging itik dan $300 \mathrm{~g}$ buah nangka muda) dengan nilai ratan sebesar 35,43\% atau sebesar 354,3 g. Sedangkan rataan rendemen terendah pada perlakuan A1 (850 daging itik dan 150 buah nangka muda) dengan nilai rataan sebesar $28,37 \%$ atau sebesar $283,7 \mathrm{~g}$.

Tabel 3. pH abon daging itik afkir dengan penambahan buah nangka muda

\begin{tabular}{ccccc}
\hline \multirow{2}{*}{ Ulangan } & \multicolumn{4}{c}{ Perlakuan } \\
\cline { 2 - 5 } & $\mathrm{A} 0$ & $\mathrm{~A} 1$ & $\mathrm{~A} 2$ & $\mathrm{~A} 3$ \\
\hline 1 & 5,02 & 5,04 & 4,40 & 3,84 \\
2 & 5,09 & 4,75 & 4,44 & 4,02 \\
3 & 4,81 & 4,96 & 4,84 & 5,13 \\
\hline Rataan & $4,97 \pm 0.15$ & $4,92 \pm 0.15$ & $4,56 \pm 0.24$ & $4,33 \pm 0.70$ \\
\hline
\end{tabular}

Keterangan : tidak berpengaruh nyata $(\mathrm{P}>0,05)$ 
Tabel 4.Rendemen (\%) abon daging itik afkir dengan penambahan buah nangka muda

\begin{tabular}{ccccc}
\hline \multirow{2}{*}{ Ulangan } & \multicolumn{5}{c}{ Perlakuan } \\
\cline { 2 - 5 } & A0 & A1 & A2 & A3 \\
\hline 1 & 30,50 & 30,40 & 35,50 & 31,90 \\
2 & 32,60 & 26,70 & 39,90 & 35,10 \\
3 & 31,60 & 28,00 & 30,90 & 33,10 \\
\hline Rataan & $31,57 \pm 1,50$ & $28,37 \pm 1,88$ & $35,43 \pm 4,50$ & $33,37 \pm 1,62$ \\
\hline
\end{tabular}

Keterangan : tidak berpengaruh nyata $(\mathrm{P}>0,05)$

Artinya bahwa telah terjadi penyusutan bobot bahan pangan cukup tinggi yang disebabkan selama proses pembuatan abon, yakni pada tahap pengukusan dan penggorengan akibatnya terjadi penguapan dan pengeluaran kadar air dari dalam bahan pangan.

Proses transfer panas dari air ke daging selama proses pemasakan menyebabkan suhu titik tengah daging naik, mula-mula suhu titik tengah daging sama dengan suhu air $\left(27,9^{\circ} \mathrm{C}\right)$. Ketika pressure cooker mulai dipanasi, maka suhu air naik lebih cepat dari pada suhu titik tengah daging dan pada akhirnya suhu titik daging sama dengan suhu air (Saparuddin et al., 2016). Suhu dan lama pemasakan mempunyai efek yang sangat signifikan terhadap sifat-sifat fisik dan kualitas daging. Peningkatan suhu dapat meningkatkan denaturasi protein-potein miofibril, sehingga menyebabkan terjadinya perubahan sifat-sifat protein tersebut, termasuk kemampuannya mengikat air (Jamhari et al., 2007). Segovia et al. (2007) menyatakan bahwa meningkatnya suhu menyebabkan jumlah air yang diikat menurun sehingga jumlah cairan daging yang keluar selama pemasakan menjadi lebih besar.

\section{Warna}

Warna umumnya merupakan unsur penilaian awal seseorang terhadap suatu produk makanan. Sebelum faktor lain dipertimbangkan, secara visual faktor warna memegang peranan yang sangat penting. Oleh karena itu, penerimaan konsumen terhadap suatu produk makanan seringkali dimulai dengan melihat penampakan warnanya. Warna abon daging itik afkir dengan penambahan buah nangka muda dapat dilihat pada Tabel 5.

Berdasarkan hasil analisis ragam menunjukan terhadap warna abon daging itik afkir dengan penambahan buah nangka muda tidak berpengaruh nyata $(\mathrm{P}>0,05)$, penilaian panelis terhadap warna berkisar antara 2,18-2,71\% yang berarti cenderung "disukai". Warna abon yang dihasilkan pada penelitian ini adalah warna coklat. Warna coklat merupakan warna abon secara umum.Pada perlakuan A1 kombinasi (85\% daging itik dan $15 \%$ buah nangka muda) merupakan yang paling disukai panelis dari segi warna dibandingkan perlakuan lain. Hal ini diduga dipengaruhi oleh proses penggorengan. Pada proses penggorengan akan terjadi perubahan warna menjadi coklat seperti pada produk abon umumnya.

Warna suatu produk makanan berasal dari campuran bahan makanan tersebut. Adapun faktor yang menyebabkan warna cokelat pada abon yaitu gula yang merupakan bahan pembuat abon dan kandungan karbohidrat yang tinggi sehingga menyebabkan warna abon cokelat karena terjadinya reaksi maillard. Reaksi maillard adalah reaksi pencokelatan non enzimatis yang merupakan reaksi antara protein dengan gula-gula pereduksi (Muchtadi \& Ayustaningwarno, 2010).

Warna pada abon dipengaruhi oleh perlakuan pada saat sebelum dan sesudah penggorengan, pemasakan yang berbeda menghasilkan perbedaan kadar air, sehingga pada saat penggorengan akan terjadi perbedaan panas dari minyak yang masuk ke daging (Ketaren, 2008). Perubahan warna coklat ini muncul akibat adanya proses pencoklatan atau reaksi Mailard pada bahan pangan tersebut yang disebabkan oleh penggunaan suhu penggorengan yang tinggi serta viskositas minyak goreng yang meningkat menyebabkan warna pada minyak lebih mudah menempel pada bahan pangan yang digoreng (Zahra, et al., 2013). 
Tabel 5. Warna abon daging itik afkir dengan penambahan buah nangka muda

\begin{tabular}{ccccc}
\hline \multirow{2}{*}{ Ulangan } & \multicolumn{5}{c}{ Perlakuan } \\
\cline { 2 - 5 } & A0 & A1 & A2 & A3 \\
\hline 1 & 2,07 & 2,27 & 2,33 & 2,80 \\
2 & 2,47 & 2,33 & 2,60 & 3,13 \\
3 & 2,13 & 1,93 & 1,73 & 2,20 \\
\hline Rataan & $2,22 \pm 0,21$ & $2,18 \pm 0,21$ & $2,22 \pm 0,44$ & $2,71 \pm 0,47$ \\
\hline
\end{tabular}

Keterangan : tidak berpengaruh nyata $(\mathrm{P}>0,05)$

Tabel 6.Aroma abon daging itik afkir dengan penambahan buah nangka muda

\begin{tabular}{ccccc}
\hline \multirow{2}{*}{ Ulangan } & \multicolumn{5}{c}{ Perlakuan } \\
\cline { 2 - 5 } & A0 & A1 & A2 & A3 \\
\hline 1 & 2,53 & 2,53 & 2,67 & 2,60 \\
2 & 2,33 & 2,20 & 2,47 & 2,47 \\
3 & 2,20 & 1,87 & 1,80 & 1,93 \\
\hline Rataan & $2,36 \pm 0,17$ & $2,20 \pm 0,33$ & $2,31 \pm 0,45$ & $2,33 \pm 0,35$ \\
\hline
\end{tabular}

Keterangan : tidak berpengaruh nyata $(\mathrm{P}>0,05)$

\section{Aroma}

Bersama-sama dengan warna, rangsangan bau atau aroma turut menentukan tingkat penerimaan suatu produk makanan, dalam banyak hal, penerimaan makanan ditentukan oleh aromanya. Meskipun penampakan produk makanan disukai tetapi akan mengurangi daya penerimaannya bila terjadi penyimpangan aroma. Aroma abon daging itik dengan penambahan buah nangka muda dapat dilihat pada Tabel 6 .

Berdasarkan hasil analisis ragam organoleptik terhadap parameter aroma abon daging itik afkir dengan penambahan buah nagka muda pada setiap perlakuan tidak pengaruh nyata $(\mathrm{P}>0,05)$, penilaian panelis berkisar antara 2,20$2,36 \%$ yang berarti aroma abon "disukai" oleh panelis. Aroma abon yang dihasilkan dari penelitian ini adalah khas daging yang digoreng, dalam hal ini tidak ada panelis yang mengeluhkan adanya aroma asing. Aroma yang dihasilkan pada produk abon daging itik ini secara umum dipengaruhi oleh bumbu yang digunakan, sedangkan faktor lain yang berpengaruh adalah proses penggorengan. Dimana selama penggorengan, minyak akan mengalami oksidasi menjadi senyawa antara peroksida yang tidak stabil (Choe \& Min, 2007). Penggorengan lebih lanjut akan merubah sebagian peroksida dan asam lemak bebas yang mempengaruhi makanan gorengan (Putri et al., 2016).

Dari keempat jenis perlakuan yang digunakan, secara umum dapat diterima oleh panelis karena bumbu yang digunakan memiliki takaran yang sama pada masing-masing perlakuan.
Aroma produk abon daging diduga berasal dari lemak dan bumbu yang digunakan sehingga dapat memberikan aroma abon yang khas. Menurut Pakaya et al. (2015) yang meneliti abon ikan, diduga bau yang enak dari abon ikan juga berasal dari kandungan glutamate yang tinggi pada ikan cakalang sehingga memberikan cita rasa dan aroma yang khas dan juga pengaruh bumbu yang digunakan. Bumbu-bumbu yang digunakan dalam penelitian ini terdiri dari bawang putih, bawang merah, lada, ketumbar, kemiri, laos, daun salam dan sereh.Aroma biasanya akibat dari adanyacampuran berbeda, kadang-kadang banyak senyawa yang berbau.Bahan atau senyawa yang ditambahkan pada makanan untuk meningkatkan cita rasa biasanya zat-zat yang mengandung senyawa atsiri (Brown, 2009). Senyawa atsiri yang digunakan umumnya diperoleh dari bahan tumbuh-tumbuhan dan rempah-rempah (Winarno, 2008).

\section{Tekstur}

Tekstur merupakan interaksi yang ditimbulkan oleh suatu bahan pangan yang dapat dibedakan oleh indera peraba. Salah satu faktor yang menentukan kualitas makanan adalah tekstur, segingga turut serta mempengaruhi daya tarik seseorang terhadap makanan. Tekstur abon daging itik dengan penambahan buah nangka muda dapat dilihat pada Tabel 7.

\section{Rasa}

Rasa merupakan bagian penting dari suatu produk makanan. Rasa sebagai faktor penentu daya terima konsumen terhadap produk pangan. Dalam penilaian rasa lebih bnayak menggunkan 
alat indra perasa. Pengindraan rasa dibagi menjadi 4 faktor yaitu asin, asam, manis,dan pahit (Montolalu et al., 2013). Skor rasa abon daging itik afkir dan dengan penambahan buah nagka muda dapat dilihat pada Tabel 8. Berdasarkan hasil analisis ragam organoleptik terhadap rasa parameter abon daging itik afkir dan dengan penambahan buah nangka muda tidak berpengaruh nyata $(\mathrm{P}>0,05)$.

Tabel 7.Tekstur abon daging itik afkir dengan penambahan buah nangka muda

\begin{tabular}{crrrr}
\hline \multirow{2}{*}{ Ulangan } & \multicolumn{5}{c}{ Perlakuan } \\
\cline { 2 - 5 } & \multicolumn{1}{c}{ A0 } & A1 & A2 & A3 \\
\hline 1 & 2,60 & 2,33 & 2,67 & 2,60 \\
2 & 2,60 & 2,87 & 2,40 & 2,93 \\
& 2,60 & 2,07 & 1,67 & 2,20 \\
\hline Rataan & $2,60 \pm 0,00$ & $2,42 \pm 0,41$ & $2,24 \pm 0,52$ & $2,58 \pm 0,37$ \\
\hline
\end{tabular}

Keterangan : tidak berpengaruh nyata $(\mathrm{P}>0,05)$

Tabel 8. Rasa abon daging itik afkir dengan penambahan buah nangka muda

\begin{tabular}{ccccc}
\hline \multirow{2}{*}{ Ulangan } & A0 & A1 & A2 & A3 \\
\cline { 2 - 5 } & 2,00 & 2,13 & 2,40 & 2,40 \\
1 & 2,20 & 2,33 & 2,40 & 2,53 \\
2 & 2,00 & 2,07 & 2,00 & 1.80 \\
3 & $2,07 \pm 0,12$ & $2,18 \pm 0,14$ & $2,27 \pm 0,23$ & $2,24 \pm 0,39$ \\
\hline
\end{tabular}

Keterangan : tidak berpengaruh nyata $(\mathrm{P}>0,05)$

Nilai rataan rasa abon berkisar antara $2,07-2,27 \%$ yang berarti rasa abon tersebut cenderung "disukai". Panelis menyukai rasa abon yang dihasilkan dalam penelitian ini karena meratanya dan keseragaman bumbu yang ditambahkan. Rasa produk abon pada masingmasing perlakuan secara umum diterima oleh panelis. Rasa abon ini dipengaruhi oleh cita rasa dari bumbu-bumbu yang digunakan serta proses pengolahan yakni pengukusan dan penggorengan sehingga dapat menutupi atau menghilangkan bau anyir dari daging itik tersebut.

Fiszman (2008) menyatakan bahwa bumbu pada produk yang lapisan (coating) memberikan nilai tambah karena mampu meningkatkan cita rasa dan aroma. Reaksi maillard yang terjadi saat proses penyangraian selain menyebabkan perubahan warna produk juga menghasilkan aroma produk. Hal ini terjadi karena adanya kondensasi gula dengan gugus amino sehingga menghasilkan glikolisis $\mathrm{N}$ tersubsitusi, amina disusun kembali menjadi amadori tidak stabil (prekusor aldosa) atau produk heyns (prekusor ketosa) selanjutnya kehilangan asam amino membentuk 1 dan 3 deoxyosone, kemudian akan mengalami berbagai rangkaian perubahan reaksi hingga membentuk senyawa aroma heterosiklik (Reiniccius, 2006).

\section{KESIMPULAN}

Abon daging itik afkir dengan penambahan buah nagka muda tidak berpengaruh nyata terhadap $\mathrm{pH}$ dan rendemen abon serta tidak mengurangi kesukaan panelis terhadap abon daging itik.

\section{DAFTAR PUSTAKA}

Brown P., 2009. Seasoning, and Flavours. Di dalam : Tarte R. editor Ingridients in Meat Products: Properties, Functionality and Applications. Research, Development \& Qualty Kraft Foods Inc.

Choe, E, \& D.B. Min. 2007. Chemitry of deep-fat frying oils. Journal of Food Science. Institute of Food Technologiests 72(5):110.

Fiszman, S.M. 2008. Quality of Battered or Breaded Product. In: Sahin S.G.Sumnu (eds). Advances Indeep Fat Frying of Foods. CRC Press. Bocaratton. p:243-261

Hafid, H. 2004. Fisik dan mutu sensori daging sapi bali yang di pelihara secara tradisional: pengaruh pelayuan dan jenis kelamin. Majalah Ilmiah Agriplus 14(1):133-138. 
Hafid, H. \& A. Syam. 2007. Pengaruh daging dan lokasi otot terhadap kualitas organoleptik daging sapi. Buletin Peternakan 31(4):209216.

Hafid, H., Nuraini, \& Inderawati. 2014. Sifat organoleptik daging itik afkir yang diberi perlakuan stimulasi listrik. Prosiding Seminar Nasional Optimalisasi Sumberdaya Pada Peternakan Rakyat Berbasis Teknologi. Peningkatan Produktivitas Ternak Lokal. Makassar, 910 Oktober 2014. Fakultas Peternakan Universitas Hasanuddin. Makassar. Hlm. 182-193.

Hafid, H. 2017. Pengantar Pengolahan Daging: Teori dan Praktik. Cetak Pertama. Penerbit Alfabeta. Bandung.

Hafid, H., Nuraini, D. Agustina, Fitrianingsih, dan Inderawati. 2017. Kualitas organoleptik nugget yang di subtitusi usus ayam. Prosiding Seminar Nasional Industri Peternakan. Peningkatan Implementasi Inovasi Riset pada Industri Peternakan. Bogor 29-30 November 2017. Fakultas Peternakan Institut Pertanian Bogor. Bogor, Hlm. 72-77.

Jamhari, E. Suryanto, \& Rusman. 2007. Pengaruh temperatur dan lama pemasakan terhadap keempukan dan kandungan kolagen daging sapi. Buletin Peternakan 31(2):94-100.

Joseph, G., H.T.Uhi, I. Wahyuni, S.Y. Ramda, H. Hafid, Rukmiasih, \& A. Parakkasi. 2002. Status kolesteral itik mandalung dengan pemberian serat kasar dan vitamin C. Prosiding Seminar Nasional Peternakan dan Veteriner 2002. Ciawi-Bogor 28-29 September 2002. Puslitbang Peternakan, Bogor. Hlm. 151-160.

Ketaren, S. 2008. Pengantar Teknologi Minyak dan Lemak Pangan. Cetakan Pertama. Universitas Indonesia Press. Jakarta.

Montolalu, S., N. Lantaan., S. Sakul, \& A.D. Mirah. 2013. Sifat fisik, kimia dan mutu organoleptik bakso broiler dengan menggunakan tepung ubi jalar (Ipomoea Batatas L). Zootek 32(5):1-13.

Muchtadi, T.R., \& F. Ayustaningwarno. 2010. Teknologi Proses Pengolahan Pangan. Alfabeta. Bandung.

Pakaya, R., L.C. Mandey, \& F. Lumoindong. 2015. Pengaruh penambahan jantung pisang goroho (musasp.) terhadap kandungan gizi dan organoleptik abon ikan cakalang (Katsuwonus pelamis). J. Ilmu dan Teknologi Pangan 3(2):15-23.

Pursudarsono.F., R. Djalal, \& A. S. Widati. 2015. Pengaruh perlakuan imbangan garam dan gula terhadap kualitas dendeng paru-paru sapi. Jurnal Ilmu dan Teknologi Hasil Ternak 10(1):35-45.

Putri, R.I., Budiyanto, \& Syafnil. 2016. Kajian kualitas minyak goreng pada penggorengan berulang ikan lemuru (Sardinella lemuru). Jurnal Agroindustri 6(1):1-7.

Randa, S.Y., I. Wahyuni, G. Joseph, H.T.Uhi, Rukmiasih, H. Hafid, \& A. Parakkasi. 2002. Efek pemberian serat tinggi dan vitamin $\mathrm{c}$ terhadap produksi karkas dan non kakas itik mandalung. Prosiding Seminar Nasional Peternakan dan Veteriner 2002. CiawiBogor 28-29 September 2002. Puslitbang Peternakan, Bogor. Hlm. 261-264.

Reineccius, G. 2006. Flavour Chemistry and Teknology. Second Edition. Boca Raton: CRC Press, LLC.

Saparudin, D. Wulandani, \& N. Purwanti. 2016. Validasi simulasi tekanan dan suhu air serta suhu daging sapi selama pemasakan dalam pressure cooker. Jurnal Teknologi Industri Pertanian 26(3):343-351.

Segovia G, A.A. Bello, \& Monzo J.M. 2007. Effect of cooking method on mechanical properties. color and structure of beef muscle (M pectoralis). J Food Eng. 80:813821.

Soeparno. 2005. Ilmu dan Teknologi Daging. Gajah Mada University Press. Yogyakarta.

Tetty, H.D., Rumbia, \& L. Gloria. 2007. Pemanfaatan daging kelinci dalam pembuatan abon dengan penambahan buah nangka muda serta analisis mutu fifik dan mutu gizinya. Jurnal Ilmiah PANNMED. $1(2): 49-55$.

Winarno F.G., 2008. Kimia Pangan dan Gizi Edisi Terbaru. M-Brio Press. Bogor.

Zahra, S.L., B. Dwiloka, \& S. Mulyani. 2013. Pengaruh penggunaan minyak goreng berulang terhadap perubahan nilai gizi dan mutu hedonik pada ayam goreng. Animal Agriculture Journal, 2(1):253260. 